Investigations

\title{
Efficiency of Microtubers Application in the Production of Original Potato Seeds
}

\author{
${ }^{1}$ Zhursinkul Abdugapparovna Tokbergenova, ${ }^{1}$ Sailau Akhmetovich Babayev, \\ ${ }^{1}$ Dauriya Urazgaliyevna Togayeva, ${ }^{1}$ Danara Zhumabekovna Kudusbekova and \\ ${ }^{2}$ Aleksey VasilievichZagurskii \\ ${ }^{I}$ Kazakh Research Institute of Potato and Vegetable Growing, \\ 040917, Almaty Region, Karasay Region, Kaynar Town, Nauryz Street 1, Republic of Kazakhstan \\ ${ }^{2}$ Kyrgyz National Agrarian University named after K.I. Scryabin, \\ Bishkek, Mederova Street 68, Kyrgyz Republic
}

Article history

Received: 11-09-2017

Revised: 03-10-2017

Accepted: 03-11-2017

\section{Corresponding Author:}

Zhursinkul Abdugapparovna

Tokbergenova

Kazakh Research Institute of

Potato and Vegetable Growing, 040917, Almaty region,

Karasay Region, Kaynar Town,

Nauryz Street 1, Republic of

Kazakhstan

E-mail:tokbergenova-

zhursinkul@yandex.ru

\begin{abstract}
The development of the technology of mass microtubers cultivation in vitro based on innovative methods with respect to potato varieties allowed for use in Kazakhstan has an important theoretical and practical significance for the development of seed production in the Republic. The goal is to develop a technology for mass cultivation of potatoes microtubers in vitro based on biotechnology methods and to assess the possibility of their use as a starting material in the seed-growing process of potatoes. Research methods are generally accepted in plant biotechnology. For the first time, studies are carried out on the mass cultivation of microtubers in vitro and their testing in the field, which determines the relevance and scientific novelty. The practical significance of the project is due to the determination of the most optimal timing for in vitro production of microtubers for the original seed production of potatoes in Kazakhstan. It was revealed that the induction of potato microtubers in vitro allows to accumulate and preserve the healthy planting material of valuable varieties during the entire period without additional transplantations, creating a kind of bank, to simplify and reduce the cost of forwarding the planting material. By regulating the photoperiod, lowering the temperature and modifying the nutrient medium, the tuber formation process was induced. A conclusion is made about the possibility of using microtubers as a planting material in the seed production of potatoes.
\end{abstract}

Keywords: Potato, Original Seed Production, Microtubers, Regenerant, Culture Medium, Photoperiod, Cultivation

\section{Introduction}

In the original potato seed production, an important link is the production of the original healthy material. Improving the technology of accelerated reproduction at laboratory and in field conditions is one of the topical issues in the seed production of potatoes. At present, the introduction of improved potato varieties into production is proceeding slowly. In this regard, it is advisable to use various methods of accelerated reproduction, which make it possible to obtain high multiplication factors in the production of original potato seeds (Basiev, 2015; Deryabin, 1997). One of the ways to solve this problem is to use microtubers induced in vitro as a health improvement material.
Because of their small size and smaller mass, the use of microtubers as a planting material reduces the cost of planting, storage (less storage capacity required) and seed transportation (Makarov, 1990; Matevossian et al., 1990).

The production of microtubers also has a number of advantages over the existing method of microclonal reproduction of test plants.

When propagating by microtubers, the multiplication factor (up to 7-8 times) and labor productivity increase, year round viral and diseases free micro and minitubers are produced, at the same time there is a real possibility of accelerated reproduction and wide introduction of new varieties of Kazakhstan breeding (Tokbergenova, 2016).

The method of cultivation of microtubers in vitro is actively being developed in a number of foreign 
countries (USA, Canada, Great Britain, France, Denmark, the Netherlands, South Korea, China) in order to use it as a planting material in potato seed production. In the UK, by the company "Gudron and Innes" and in France a technology for year-round production of "basic" microtubers with a diameter of 4-12 mmwas developed (Shukurova et al., 2007; Hannapel, 2007).

According to the forecasts of scientists CIP (International Center for Potatoes, Peru), tubers obtained in vitro, are widely used in various schemes for the production of seed tubers. A group of American scientists at the University of Wisconsin studied the growth and development of tubers of early and late maturing varieties in the field conditions (Wang and $\mathrm{Hu}$, 1985; Wareh et al., 1989; Wareing et al., 1980).

According to many authors for tuber formation in test tubes, the duration of the light and dark periods of the day, as well as the temperature factor are very important. Conditions of a short day and low temperatures contribute to tuber formation, a long day and high temperatures slow this process down up to its full braking (Balashova, 2015b; TPPOERSP, 2011; Anisimov and Smolegovets, 2008). The mechanism of photoperiodic induction of tuber formation is based on a change in the ratio and level of phytohormones.

All the plant hormones known at the present timeauxins, gibberellins, abscisins, cytokinins participate in the regulation of tuber formation. The data of many researchers indicate that when phytohormones inductors are injected into the culture medium in vitro, effective stimulation of tuber formationwas obtained (Rogrigues-Falcon et al., 2006; Koksharova, 2004; Anisimov et al., 2014).

Achieving the optimal ratio of factors that stimulate the formation of tubers in potatoes, you can get more of them and in the earlier periods. Such microtubers, used as a virus-free planting material, are the "ideal end product of micropropagation of potatoes", convenient for storage and transportation (Owes et al., 2014).

Researchers at the Korean Research Institute of Bio Science and Biotechnology have indeed achieved the goal of developing an unexplored and innovative technology in which the production efficiency is at least 100 times higher than in traditional technology. Currently, this technology is industrialized in Korea and 30 million microtubers of different species are produced and distributed among numerous local and foreign farmers with excellent field test results (Owes et al., 2014; Pelacho et al., 1994).

With the purpose of improving the technology of inducing biotechnological microtubers in vitro - the sources of the virus-free planting stock of seed potatoes, since 2002 a series of experiments have been carried out in the laboratory of biotechnology of the Kazakh Scientific Research Institute. The main attention was paid to the photoperiodic factors of tuber formation, the influence of certain components of the nutrient medium on it, as well as the temperature regimes during storage of microtubers.

Kazakhstan scientists developed a laboratory regulation on the accelerated induction of potato microtubers in vitro with a complex of biotechnological parameters (Tokbergenova et al., 2010).

Based on the foregoing, undoubtedly, the development and introduction of the technology of mass production of microtubers for the subsequent production of virusfree seed can produce a green revolution in potato cultivation. The use of healthy microtubers in seed production will allow farmers and farms to obtain a high yield and hence profit.

\section{Materials and Methods}

Laboratory and field experiments and the processing of their results were carried out in accordance with existing recommendations and guidelines.

The object of the study was the new varieties of potato selection of the Kazakh Scientific Research Institute of Potato and Vegetable Growing: Aksor, Zhanaisan, Tamyr, Tokhtar and Nerli.

Improvement of plant material was carried out by the method of culture of the apical meristem in combination with thermotherapy using the methodical recommendations of (Rakhimbaev, 1985; Kataeva and Butenko, 1983).

Plants-regenerants, reached the height of the test tube, are grafted in aseptic conditions. Before passivation on the nutrient medium for tuber formation, the cuttings were tested for viruses by the method of enzyme immunoassay (ELISA).

The middle parts of the cuttings of the sanitized plants were placed in sterile jars with the MurashigeSkoog nutrient medium containing tuber inducers.

To accelerate the process of tuber formation in vitro and improve their quality at the laboratory, a set of techniques were used.

During the experiments, the following factors were studied: Photoperiod - $16 \mathrm{~h}$ and constant darkness; concentration of 6-Benzylaminopurine (6-BAP) - 0,5; 1,0; 2,0 и 3,0 mg/L; Concentration of Indoleacetic Acid (IAA) -125 mg/L, adenine - $40 \mathrm{mg} / \mathrm{L}$ and kinetin concentration - $1 \mathrm{mg} / \mathrm{L}$.

During the work on selection of nutrient media, solid, agar media were tested. In a nutrient medium, an elevated concentration $(80,000 \mathrm{mg} / \mathrm{L})$ of sucrose was used as a control, as inducers of the formation of microtubers were used: Benzylaminopurine, kinetin and adenine, that are, the components that together regulate the process of tuber formation of micro-plants in vitro. The results were determined as the tubers appeared.

After transferring on the nutrient medium, cuttings in vessels (jars) were cultivated in a phytotron at a temperature of $22^{\circ} \mathrm{C}$, with a lighting of 3-5 thousand $1 \mathrm{x}$, 
with a 16 -h photoperiod for 3,7 and 15 days. Then they were transferred to a constant darkness.

The experience was laid to study the influence of the mass of microtubers on the productivity of the seed material under in vivo conditions.Experiment variants: 100$200 ; 200-400 ; 400-600 \mathrm{~mm}$. The influence of the microtuber planting scheme on the productivity of seed in field conditions is determined. Trials were by variants: $70 \times 5 ; 70 \times 10 ; 70 \times 15 ; 70 \times 20 ; 70 \times 25$ and $70 \times 30 \mathrm{~cm}$.

The number of microtubers from each variety is 100 pieces. Repetition of the experiment is 4-fold.

\section{Statistical Analysis}

The obtained data of laboratory and field experiments were statistically processed by means of dispersion analysis according to the experimental procedure (Dospekhov, 1985). In this case, the smallest significant difference was calculated.

\section{Results and Discussion}

Possibility of using the growth regulator of 6Benzylaminopurine (6-BAP) from the cytokinin group, varying the concentration from 0.5 to $2.0 \mathrm{mg} / \mathrm{L}$ has been studied to accelerate the process of in vitro tuber formation and improve their quality. As a control, the Murashige-Skoog base medium was used with a sucrose concentration of $80,000 \mathrm{mg} / \mathrm{L}$. Accounting for the beginning of microtubers formation was carried out visually, upon their appearance on plants.

The results of the study showed that, when 6-BAP at a concentration of $2 \mathrm{mg} / \mathrm{L}$ was added to the nutrient medium, the regenerating plants of the varieties Aksor, Zhanaisan, Tokhtar and Nerli formed microtubers for 5563 days, that at the level of the control variant, for which the given index was 56-64 days (Fig. 1).

According to Fig. 1, using 6-BAP was not acceptable to accelerate the microtubers formation in vitro.

Many authors confirm that auxins and cytokinins in combination promote accelerated tuber formation in vitro, since such a combination of phytohormones is possible in a culture medium designed to induce microtubers (Ogluzdin, 1981; Ostapenko, 1981).

In this regard, the experience on the modification of the nutrient medium with phytohormones (indolylacetic acid $0.125 \mathrm{mg} / \mathrm{L}$, adenine $-40 \mathrm{mg} / \mathrm{L}$ and kinetin - $1 \mathrm{mg} / \mathrm{L}$ ) for induction potato tuber formation in vitro has been laid.

The results showed, with a joint action, phytohormones contributed to the formation of microtubers after 20-27 days, and in the control variant-56-64 days, respectively. The time dependence of tuber formation in vitro on the varietal characteristics of potato was also established (Fig. 2).

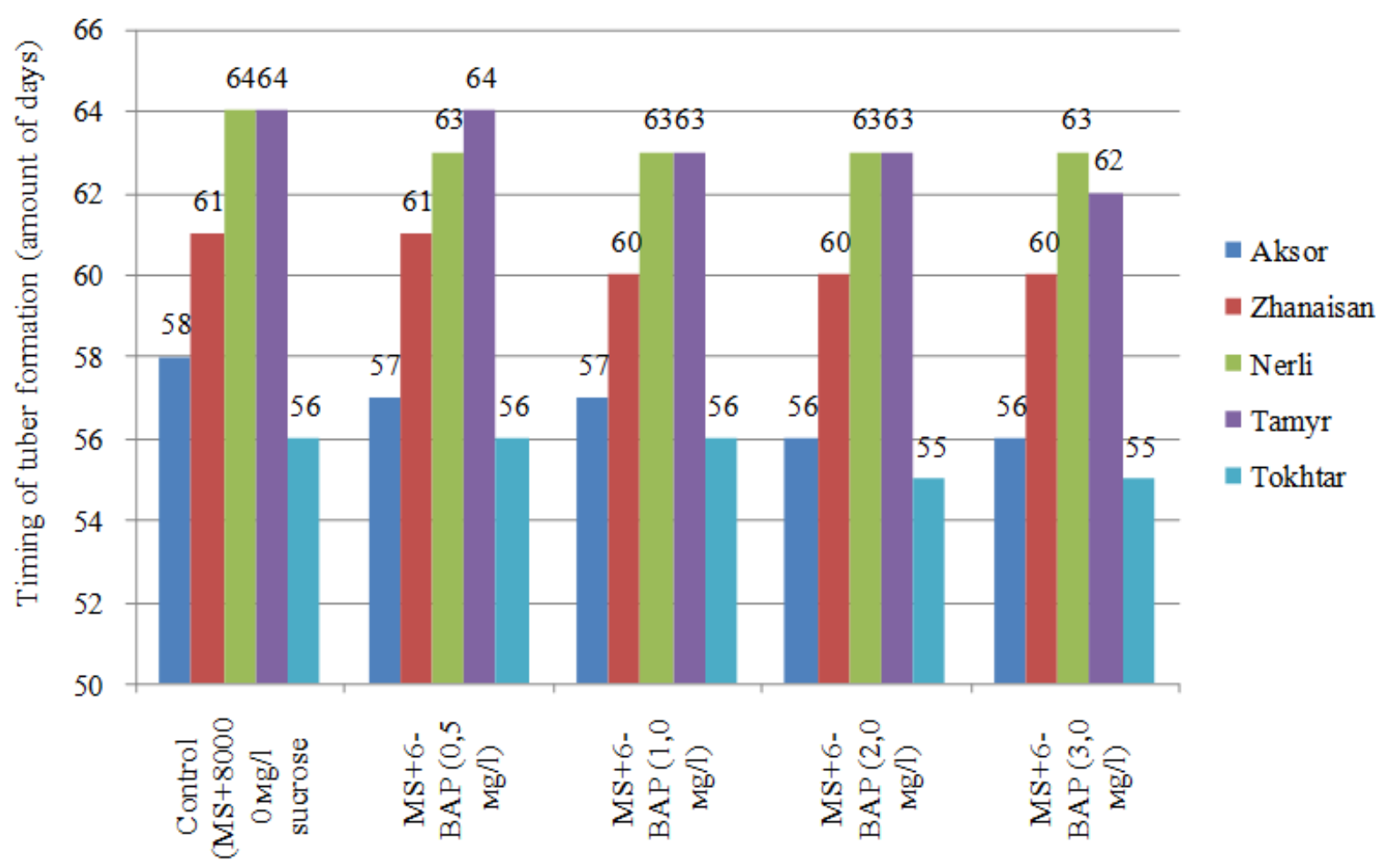

Fig. 1: Effect of 6-BAP on in vitro potato tuber formation 


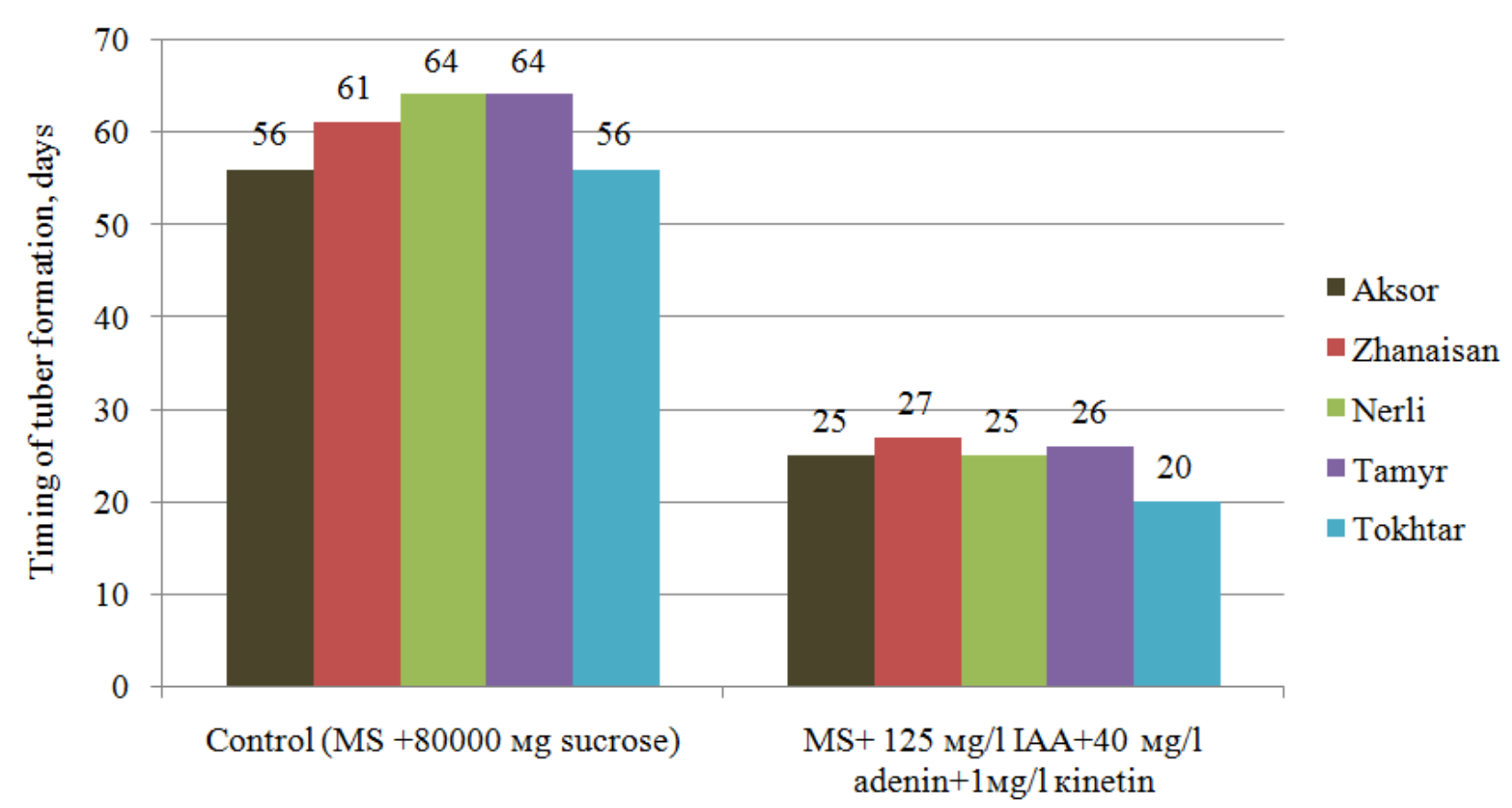

Fig. 2: The timing of in vitro potato tuber formation, depending on the composition of the nutrient medium

The earliest terms of tuber formation on the experimental variants were observed in the middleripening Tokhtar variety, in which the plants formed microtubers on the 20th day, the middle-ripening varieties of Aksor and Nerli formed microtubers on the 25th day. In the varieties Tamyr and Zhanaisan tuber formation was observed at a later date, on the 26-27th day.

The experiments showed that for all tested varieties the optimal medium for accelerated formation of microtubers turned out to be a medium containing IAA $125 \mathrm{mg} / \mathrm{L}$, adenine - $40 \mathrm{mg} / \mathrm{L}$ and kinetin $-1 \mathrm{mg} / \mathrm{L}$.

It should also be noted that the abovementioned phytohormones positively influenced the increase in the number, size and accumulation of mass of microtubers induced in vitro.

By the number, size and mass of the potato microtubers, the accounting were carried out on the 20th day after the appearance of nodules (Table 1).

The number of microtubers per plant in the experimental variant was up to 2.1 pieces, depending on the genotype of the potato, while on the control variant it was 1.0 piece. In all tested varieties, the size of microtubers increased by $2.2-6.0 \mathrm{~mm}$ compared to the control variant, which was from $6.0 \mathrm{~mm}$ to $9.0 \mathrm{~mm}$.A similar trend was observed in the mass of microtubers from $490.0 \mathrm{mg}$ to $692.0 \mathrm{mg}$, which is important in the system of potatoes seed production.

When studying inducers of tuber formation, the varietal feature of potato was clearly distinguished. It was established that the highest tuber capacity for the timing and quantity of microtubers was noted in plants of the middle ripening variety Tokhtar, which in the medium containing IAA, adenine and kinetin appeared microtubers on 20.0 days in an amount of 2.1 pieces per plant, that is, the maximum number of tubers among all tested varieties. By weight and size, it was inferior to the middle-ripening varieties of Nerli and Tamyr.

Hormonal regulation of tuber formation in vitro is associated with a number of factors, including the complex effect of the duration of the photoperiod with inducers of microtuber formation (Balashova, 2015a).

In this regard, we considered the options: A-plantsregenerants, cultivated with a 16-h photoperiod for 15 days and transferred to a constant darkness); Bregenerative plants cultivated with a 16 -h photoperiod for 7 days and transferred to a constant darkness; Cregenerative plants cultivated for a 16 -h photoperiod for 3 days and transferred to a constant darkness.

The photoperiod in combination with the nutrient medium had a significant effect on the intensity of tuber formation (Table 2).

The maximum values for the number and mass of microtubers were obtained by reacting a $16-\mathrm{h}$ photoperiod for 3 days with transfer to a constant darkness and a concentration of phytohormones (indolylacetic acid-125 $\mathrm{mg} / \mathrm{L}$; adenine - $40 \mathrm{mg} / \mathrm{L}$; kinetin- $1 \mathrm{mg} / \mathrm{L}$ ). At the same time, the number of microtubers per plant of varieties Aksor and Tokhtar, was 1.9-2.1, the mass of these microtubers was 462.0-489.4 mg, respectively.

The next stage is the experience of study the effect of microtuber mass on in vivo seed productivity. 
Table 1: Effect of phytohormones on the yield of in vitro potato micro tubers

\begin{tabular}{|c|c|c|c|c|}
\hline Varieties & Treatments & $\begin{array}{l}\text { Amount of microtubers } \\
\text { per } 1 \text { plant, piece }\end{array}$ & $\begin{array}{l}\text { Size of } \\
\text { microtuber, } \mathrm{mm}\end{array}$ & $\begin{array}{l}\text { Mass of } 1 \\
\text { microtuber, mg }\end{array}$ \\
\hline Aksor & $\begin{array}{l}\text { Control (MS+80000 mgsucrose) } \\
\mathrm{MS}+125 \mathrm{mg} / \mathrm{L} \text { IAA }+ \\
+40 \mathrm{mg} / \mathrm{L} \text { adenine }\end{array}$ & 1,0 & 4,0 & 295,0 \\
\hline $\mathrm{SD}$ & $+1 \mathrm{mg} / \mathrm{L}$ kinetin & 1,67 & 6,8 & $\begin{array}{l}526,0 \\
0,81\end{array}$ \\
\hline Zhanaisan & $\begin{array}{l}\text { Control (MS }+80000 \text { mgsucrose) } \\
\mathrm{MS}+125 \mathrm{mg} / \mathrm{L} \mathrm{IAA}+ \\
+40 \mathrm{mg} / \mathrm{L} \text { adenine }\end{array}$ & 1,0 & 3,8 & 205,0 \\
\hline & $+1 \mathrm{mg} / \mathrm{L}$ kinetin & 2,0 & 6,0 & 490,0 \\
\hline Nerli & $\begin{array}{l}\text { Control (MS + } 80000 \text { mgsucrose) } \\
\mathrm{MS}+125 \mathrm{mg} / \mathrm{L} \text { IAA }+ \\
+40 \mathrm{mg} / \mathrm{L} \text { adenine }\end{array}$ & 1,0 & 3,9 & 330,0 \\
\hline & $+1 \mathrm{mg} / \mathrm{L}$ kinetin & 1,9 & 7,8 & 692,0 \\
\hline SD & & & & 1,02 \\
\hline Tamyr & $\begin{array}{l}\text { Control (MS }+80000 \text { mgsucrose) } \\
\mathrm{MS}+125 \mathrm{mg} / \mathrm{L} \mathrm{IAA}+ \\
+40 \mathrm{mg} / \mathrm{L} \text { adenine }\end{array}$ & 0,92 & 3,0 & 332,0 \\
\hline & $+1 \mathrm{mg} / \mathrm{L}$ kinetin & 1,8 & 9,0 & 647,9 \\
\hline Tokhtar & $\begin{array}{l}\text { Control (MS }+80000 \text { mgsucrose) } \\
\mathrm{MS}+125 \mathrm{mg} / \mathrm{L} \mathrm{IAA} \mathrm{+} \\
+40 \mathrm{mg} / \mathrm{L} \text { adenine }\end{array}$ & 1,0 & 3,2 & 200,0 \\
\hline SD & $+1 \mathrm{mg} / \mathrm{L}$ kinetin & 2,1 & 7,6 & $\begin{array}{l}561,3 \\
0,62\end{array}$ \\
\hline
\end{tabular}

Table 2: In vitro tuber formation of potato depending on the photoperiod and nutrient medium, 2015-2016

\begin{tabular}{|c|c|c|c|c|}
\hline Varieties & $\begin{array}{l}\text { Cultivation conditions, } \\
\text { photoperiod }\end{array}$ & $\begin{array}{l}\text { Phytohor-mones } \\
\text { nutrient medium } \\
\text { concentration in }\end{array}$ & $\begin{array}{l}\text { Amount of } \\
\text { microtubers per } \\
1 \text { plant, piece }\end{array}$ & $\begin{array}{l}\text { Mass of } 1 \\
\text { microtuber, } \\
\mathrm{mg}\end{array}$ \\
\hline \multirow[t]{3}{*}{ Aksor } & $\begin{array}{l}\text { Cultivation of plants with a } 16-\mathrm{h} \\
\text { photoperiod for } 15 \text { days and transferring } \\
\text { them to a constant darkness }\end{array}$ & $\begin{array}{l}\mathrm{MS}+125 \mathrm{mg} / \mathrm{L} \mathrm{IAA}+ \\
+40 \mathrm{mg} / \mathrm{L} \text { adenine } \\
+1 \mathrm{mg} / \mathrm{L} \text { kinetin }\end{array}$ & 0,9 & 178,0 \\
\hline & $\begin{array}{l}\text { Cultivation of plants with a } 16-\mathrm{h} \\
\text { photoperiod for } 7 \text { days and transferring } \\
\text { them to a constant darkness }\end{array}$ & & 1,0 & 429,2 \\
\hline & $\begin{array}{l}\text { Cultivation of plants with a } 16-\mathrm{h} \\
\text { photoperiod for } 3 \text { days and transferring } \\
\text { them to a constant darkness }\end{array}$ & & 1,09 & 462,0 \\
\hline SD & & & & 1,1 \\
\hline \multirow[t]{3}{*}{ Tokhtar } & $\begin{array}{l}\text { Cultivation of plants with a } 16-\mathrm{h} \\
\text { photoperiod for } 15 \text { days and transferring } \\
\text { them to a constant darkness }\end{array}$ & $\begin{array}{l}\mathrm{MS}+125 \mathrm{mg} / \mathrm{L} \text { IAA }+ \\
+40 \mathrm{mg} / \mathrm{L} \text { adenine } \\
+1 \mathrm{mg} / \mathrm{L} \text { kinetin }\end{array}$ & 0,9 & 210,0 \\
\hline & $\begin{array}{l}\text { Cultivation of plants with a } 16-\mathrm{h} \\
\text { photoperiod for } 7 \text { days and transferring } \\
\text { them to a constant darkness }\end{array}$ & & 1,0 & 350,0 \\
\hline & $\begin{array}{l}\text { Cultivation of plants with a } 16-\mathrm{h} \\
\text { photoperiod for } 3 \text { days and transferring } \\
\text { them to a constant darkness }\end{array}$ & & 1,2 & 489,4 \\
\hline SD & & & & 1,23 \\
\hline
\end{tabular}

On the basis of a comparative evaluation of the productivity and quantitative yield of the seed material using different microtubers in mass, the highest values were obtained when planting in vitro microtubers with a mass of 400-600 mg. In this variant, depending on the genotype, the productivity indicators were 1.0-1.2 times higher than in in vitro variants of microtubers weighing less than 400-600 mg. Depending on the varietal characteristics, the mass of tubers obtained from microtubers $6.0-9.0 \mathrm{~mm}$ in size was 395.4-415.4 g/bush, however, the quantitative indices of some varieties in this variant were less. For example, with the planting of microtubers $6,0-9,0 \mathrm{~mm}$, the number of tubers per 1 bush in the varieties Aksor and Tokhtar was 10.0-13.1, which is by 0.3-1.9 pieces fewer than in the variant with microtubers of the size 4,0-6,0 $\mathrm{mm}$ (Table 3). 
Table 3: Plant productivity and quantitative yield of minitubers depending on the size characteristics of in vitro microtubers, 2015-2016

\begin{tabular}{|c|c|c|c|c|c|}
\hline \multirow{2}{*}{$\begin{array}{l}\text { Mass of in vitro } \\
\text { microtubers, } \mathrm{mg}\end{array}$} & \multicolumn{5}{|c|}{ Mass of tubers, $g /$ bush } \\
\hline & Aksor & Zhanaisan & Nerli & Tamyr & Tokhtar \\
\hline $100-200$ & 355,2 & 366,1 & 398,3 & 385,9 & 392,6 \\
\hline $200-400$ & 395,4 & 407,5 & 412,5 & 400,1 & 415,4 \\
\hline $400-600$ & 410,2 & 451,0 & 462,3 & 501,0 & 500,0 \\
\hline SD & 0,93 & 2,08 & 1,02 & 0,88 & 1,09 \\
\hline \multicolumn{6}{|c|}{ Amount of tubers, piece/bush } \\
\hline $100-200$ & 10,3 & 15,3 & 11,9 & 10,7 & 15,0 \\
\hline $200-400$ & 10,0 & 16,4 & 12,7 & 11,5 & 13,1 \\
\hline $400-600$ & 10,0 & 16,7 & 12,9 & 12,0 & 13,1 \\
\hline
\end{tabular}

Table 4: Influence of in vitro microtubers planting scheme on seed productivity in field conditions, g/bush, 2015-2016

\begin{tabular}{|c|c|c|c|c|c|c|}
\hline \multirow[b]{2}{*}{ Experienced options } & \multicolumn{6}{|l|}{ Varieties } \\
\hline & Alliance & Aksor & Zhanaisan & Nerli & Tokhtar & Tamyr \\
\hline $70 \times 5 \mathrm{~cm}$ & 334,5 & 202,8 & 298,6 & 176,3 & 157,3 & 153,8 \\
\hline $70 \times 10 \mathrm{~cm}$ & 356,8 & 256,6 & 360,7 & 258,0 & 182,4 & 179,6 \\
\hline $70 \times 15 \mathrm{~cm}$ & 381,4 & 324,7 & 361,2 & 325,7 & 208,3 & 246,8 \\
\hline $70 \times 20 \mathrm{~cm}$ & 405,7 & 460,5 & 480,2 & 419,6 & 457,6 & 419,7 \\
\hline $70 \times 25 \mathrm{~cm}$ & 558,2 & 497,5 & 519,6 & 500,8 & 536,8 & 518,5 \\
\hline $70 \times 30 \mathrm{~cm}$ & 615,2 & 500,7 & 543,1 & 557,8 & 552,2 & 631,0 \\
\hline $\mathrm{SD}$ & 2,49 & 1,9 & 1,62 & 1,46 & 1,02 & 1,29 \\
\hline
\end{tabular}

In the experiment with the use of various planting schemes for in vitro microtubers, the most optimal performance indicators were the variants with a planting scheme of $70 \times 30 \mathrm{~cm}$. Productivity of tubers from 1 bush on this variant was up to $631,0 \mathrm{~g} /$ bush (Table 4).

\section{Conclusion}

The results of the study on phytohormone 6-BAP on the acceleration of in vitro microtubers induction showed that the growth regulator of the cytokinin group did not give a positive effect. In this case, the regenerating plants of the studied varieties formed microtubers within 55-63 days, which was at the level of the control variant, in which the given index was 56-64 days.

In all studied varieties, when $125 \mathrm{mg} / \mathrm{L}$ of IAA, 40 $\mathrm{mg} / \mathrm{L}$ of adenine and $1 \mathrm{mg} / \mathrm{L}$ of kinetin were added to the nutrient medium the dynamics of tuber formation was different from control (MS + sucrose $80,000 \mathrm{mg} / \mathrm{L}$ ). The number of microtubers per plant in the experimental variant was up to 2.1 pieces, the size of microtubers increased by 2.2-6.0 $\mathrm{mm}$ compared to the control, the mass of microtubers increased to $692.0 \mathrm{mg}$, which is important in the system of seed potato production.

The photoperiod in combination with the nutrient medium had a significant effect on the intensity of tuber formation. The maximum values for the number and mass of microtubers were obtained by reacting a 16-h photoperiod for 3 days with transfer to a constant darkness and a concentration of phytohormones. At the same time, the number of microtubers per plant of varieties Aksor and Tokhtar, was 1.9-2.1, the mass of these microtubers was $462.0-489.4 \mathrm{mg}$, respectively.
The research results on the effect of the weight of microtubers on the productivity of seed in in vivo conditions have shown that with increasing mass, the productivity of the seed material increases.

The most optimal scheme for planting microtubers in vivo was $70 \times 30 \mathrm{~cm}$.

\section{Acknowledgment}

The results of scientific research were obtained in the framework of a grant project on the topic "Development of technology for in vitro potato micro tubers mass cultivation based on innovative methods in Kazakhstan". Along with the authors of the article the research was carried out with the assistance of scientific employees of KazSRIPVGLaboratory of Biotechnology: Togayeva Dauriya Urazgalievna, Kudusbekova Danara Zhumabaevna, Masters of agricultural sciences. We express our deep gratitude to our colleagues for their active participation and significant contribution to laboratory and field research and to obtaining experimental data.

\section{Author's Contributions}

All authors participated in all experiments, coordinated the data.

\section{Ethics}

This article is original and contains unpublished material. The corresponding author confirms that all of 
the other authors have read and approved the manuscript and there are no ethical issues involved.

\section{References}

Anisimov, B.V. and D.V. Smolegovets, 2008. Innovations in the system of clonal micro-propagation of potatoes. Potatoes Vegetables, 4: 26-27.

Anisimov, B.V., E.A. Simakov, E.V. Owes, S.M. Yurlova and V.S. Chugunov et al., 2014. Efficiency of various schemes of the sequential technological process of the original seed potato production. Proceedings of the 6th Interregional Scientific and Practical Conference on Modern Potato Industry: State and Prospects of Development. (SPD'14), Cheboksary, Russia, pp: 97-105.

Balashova, G.S., 2015a. In vitro potato productivity depending on the composition of nutrient medium and physical factors of cultivation. Young Scientist, 12: $540-542$.

Balashova, G.S., 2015b. Influence of temperature, photoperiod and concentration of microsalts in a nutrient medium on in vitro potato productivity. Young Scientist, 14: 675-678.

Basiev, S.S., 2015. Production of high-quality seed potato material on the basis of in vitro. Report of the Laboratory of Selection and Seed Production of Potatoes FGBOU VO "Gorsky State Agrarian University". Vladikavkaz, Russia.

Deryabin, A.N., 1997. Characteristics of physiological stages in clonal multiplication of potato microtubers in bioreactors: Auto-abstract of diss. Candidate of Biological Sciences. Institute of Plant Physiology, Moscow, Russia.

Dospekhov, B.A., 1985. Methodology of field experience. 1st Edn., Moscow, Russia, pp: 422.

Hannapel, D.J., 2007. Signalling the Induction of Tuber Formation. In: Potato Biology and Biotechnology: Advances and Perspectives, Vreugdenhil, D. (Ed.), Elsevier, Amsterdam, pp: 237-256.

Kataeva, N.V. and R.G. Butenko, 1983. Clonal Micropropagation of Plants. 1st Edn., Nauka, Moscow, pp: 97.

Koksharova, M.K., 2004. Methods of Healing and Accelerated Reproduction of Seed Potatoes: Dis. Cand. Agricult. Sciences. 1st Edn., Ekaterinburg, Russia, pp: 150.

Makarov, P.P., 1990. Application of biotechnological methods in the selection and seed-breeding of potatoes. Selection and biotechnology of potatoes. Scientific Works of SRIPG, Moscow.

Matevossian, G.L., V.M. Buren, R.K. Baranova and R.I. Volkova, 1990. Regulation of potato growth and development. Nauka, Moscow.

Ogluzdin, N., 1981. Tuber Formation of Potato Samples in Isolated Culture. In: Ways of Intensification of Potato, Fruit and Vegetable Growing, Minsk, pp: 36-37.
Ostapenko, D., 1981. Method of preservation of potatoderived collection samples, which are recovered from infection, used for selection and genetic research and seed production. Materials IY Congress Geneticists Breeders Ukraine Kiev, 4: 44-48.

Owes, E.V., O.S. Kolesova and N.A. Fenina, 2014. In vitro cultivation of microtubers using container technology. Proceedings of the 6th Interregional Scientific and Practical Conference on Modern Potato Industry: State and Prospects of Development, Cheboksary, pp: 111-115.

Pelacho, A., M.L. Closas, C. Campabadal, A. Torres and I. Farran et al., 1994. In vitro tuberization of potato: Effect of several morphogenic regulators in light and darkness. J. Plant Physiol., 144: 705-709.

Rakhimbaev, I.R., 1985. A Methodical Guide to Practical Studies on Plant Tissue Culture. 1st Edn., Al-Farabi Kazakh National University, Almaty, pp: 28.

Rogrigues-Falcon, M., J. Bou and S. Prat, 2006. Seasonal control of tuberization in potato: Conserved elements with the flowering response. Ann. Rev. Plant Biol., 57: 151-180.

Shukurova, M., N.N. Nazarova, Z.B. Davlyatnazarova, A.F. Salimov and K. Nozimov et al., 2007. Microtubers formation of in vitro potato stolon plants, depending on the conditions of cultivation of regenerating plants. Proceedings of the Academy of Sciences of the Republic of Tajikistan, (SRT'07), Department of Biology and Medicine Sciences, pp: 39-44.

TPPOERSP, 2011. Technological process of production of original, elite and reproductive seed potatoes, Moscow: FGBU "Rosselkhozentr", VNIIKh RosAgricultural Academy.

Tokbergenova, Z.A., 2016. Potato microtubers on the basis of innovative methods. Methodical manual. Almaty: Taugul-Print LLP.

Tokbergenova Z.A., S.A. Babayev V.S. Abdildaev, 2010. Induction of Potato Microtuber in vitro. 1st Edn., Laboratory regulations. - Almaty: "Aleiron", pp: 25.

Wang, P.J. and C.Y. Hu, 1985. Potato Physiology. 1st Edn., Academicpress, London.

Wareh, H., N.L. Trolinder and J.R. Goodin, 1989. Callus initiation, shoot regeneration and micropropagation of three potato cultivars. HortScience, 24: 680-682.

Wareing, P.F. and A.M.V. Jennings, 1980. The Hormonal Control of Tuberisation of Potato. In: Plant Growth Substances. Springer, Boston, pp: 293-300.

\section{Abbreviations}

KazSRIPVG- Kazakh scientific research institute of potato and vegetable growing, MS -Murashige-Skoog, 6-BAP-6-Benzylaminopurine, IAA-indolylacetic acid, tton, $\mathrm{mg}$ - milligram, ha- hectare, $\mathrm{t} /$ ha-ton per hectare. 